\title{
Zoofolkloorseid aspekte eesti keerdküsimustes, liitsõnamängudes ja piltmõistatustes
}

\begin{abstract}
Teesid: Artiklis vaadeldakse eesti mõistatuste kolme tänapäeval populaarseimat allžanrit (keerdküsimused, liitsõnamängud ja piltmõistatused), milles tegelaskujude või teemade järgi rühmitades esildub selgesti zooloogiline aspekt. Keerdküsimustes kujutatakse loomi sarnaselt rahvajuttudega (muinasjutt, naljand, anekdoot) väga vabalt, sageli võib kohata antropomorfistlikku personifikatsiooni, kus zooloogilisele olendile projitseeritud inimlikud omadused kanduvad kindlate stereotüüpide funktsioonidesse ja loomad toimivad meie endi võrdkujuna. Liitsõnamängud viitavad eesti keele üldisele liitsõnalembusele ning zooloogilised olendid sagedaste liitsõna osistena tõendavad, et asjade, nähtuste ja omaduste nimetamisel on loomariik olnud inimesele oluliseks inspiratsiooniallikaks. Kolmandik eesti piltmõistatuste ainehulgast kujutab loomariigi esindajaid, kelle liigiomased välistunnused sobivad väga hästi graafiliseks visualiseerimiseks, ja neist on lihtne kujundada traditsiooni.

Artikli tekstinäited pärinevad internetiandmebaasidest "Eesti keerdküsimused" (www.folklore.ee/Keerdkys), "Eesti (liit)sõnamängud" (www.folklore.ee/ Sonamang) ja "Eesti piltmõistatused" (http://www.folklore.ee/Reebus).
\end{abstract}

Märksõnad: loomateemaline folkloor/zoofolkloor, mõistatuste alaliigid: keerdküsimused, liitsõnamängud, piltmõistatused

Ehkki inimene on bioloogilise evolutsiooni teel eristunud loomariigist, on ta jäänud sellega väga tihedalt seotuks. Inimese ja loomariigi sidemetest annab tunnistust rikkalik loomateemaline rahvaluule, mis on uurimisobjektina esindatud kõigis klassikalistes folkloorižanrites (nt loomadega seotud rahvausund ja -kombestik, loomad rahvalauludes, loomamuinasjutud (nt Kippar 1986), loomaparöömika (nt Krikmann 1999)), sealhulgas mõistatustes.

Aegade jooksul kogutud käsikirjalise arhiivimaterjali ja erinevates trükistes leiduvate mõistatuste põhjal koostatud tüpoloogilises paberkartoteegis ja nende alusel rajatud mõistatuste digitaalsetes andmebaasides on eesti mõistatused liigitatud tekstide vormi alusel. Muudest folkloori alaliikidest eristab mõistatusi tavaliselt ülesehitus (küsimus-vastus vorm). Vormilised iseärasused tingivad arhiivi korrastamisel ka žanrisisese taksonoomia ja oma termino- 
loogia. Tavamõistatused on üldjuhul mingi objekti või tegevuse kirjeldused (umbes 130000 üleskirjutust, nt Hall härg, seljast sööb? Veskikivi).

Selle artikli huviorbiidis on mõistatuste kolm suuremat alaliiki:

1) keerdküsimused (umbes 25000 üleskirjutust) küsisõnalise või küsisõnaühendilise algusvormeliga mõistatused, mille puhul küsija eesmärk on vastajat narritada ja haneks tõmmata (Miks jookseb jänes üle mäe? Sest läbi mäe ei saa);

2) liitsõnamängulised mõistatusküsimused e liitsõnamängud (umbes 5000 üleskirjutust) algavad enamasti küsimusega missugune? või milline?, kuid ei nõua ootuspäraseks vastuseks mitte tavakohaselt neile küsisõnadele vastavat omadussõna, vaid enamasti hoopiski liitnimisõna (Missugune lind ei laula? Mesilind);

3) piltmõistatused (umbes 7300 üleskirjutust) esindavad graafilist folkloori, mille küsimuspoole moodustab paberile joonistatud (tavaliselt raamitud) minimalistlik pilt koos selle juurde esitatud küsimusega $M i s$ on pildil?, vastuseks on aga pildil oleva nähtuse, eseme, tegevuse, olu-

korra ühe sõna või lausena antud kirjeldus (Mis on pildil Elevant silmapiiril).

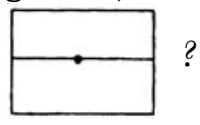

Lisaks vormilistele iseärasustele iseloomustab neid alaliike tavamõistatustega võrreldes hilisem teke ja levik. Keerdküsimuste vanim tekst on pärit Salomo Heinrich Vestringi tõenäoliselt 1720. aastatel koostatud eesti-saksa sõnaraamatu Lexicon Esthonico-Germanicum käsikirjast: Mis tulleb sündimatta ilmale? Munna (KM EKLA, ÕES, M.B. 69, 1. 154). 18. ja 19. sajandil käibinud tavamõistatustega võrreldes oli keerdküsimuste osatähtsus tollal väga väike. Liitsõnamängud on Eestis suhteliselt vana mõistatusliik, varaseimad neist pärinevad 19. sajandi keskpaiku ilmunud ajalehtede ja kalendrite lisadest, kus nad esinevad tavamõistatuste hulgas. Juba päris palju liitsõnamänge leidub Jakob Hurda ja Matthias Johann Eiseni kogutud rahvaluulematerjali seas. M. J. Eiseni koostatud mõistatuste väljaannetes (Eisen 1890, 1913 ja 1904) kohtab liitsõnamänge rohkesti, kuid suurem osa neist on kardetavasti kostaja omalooming. Vanim liitsõnamängutekst, küll ilma vastuseta avaldatud küsimus, pärineb Johann Voldemar Jannseni välja antud Sannumetoja VI numbrist. Kaheksa mõistatuse hulgas leidub üks liitsõnamäng - Missuggune kepp on keige raskem kanda? (liitsõnamängude andmebaasis arhiiviviide Sannumetoja VI (1857) 153 (2): Missugune kepp on kõige raskem? Sandikepp). Liitsõnamängude ja keerdküsimustega võrreldes on piltmõistatused märksa hilisema tekkega. Vanim arhiivitekst pärineb 1963. aastast, kuid Eesti koolilaste hulgas saavutasid piltmõistatused populaarsuse 1980. aastatel, arhiivimaterjali põhimass pärineb aga aastast 1992, mil toimus üle-eestiline koolipärimuse kogumise aktsioon. 
Kõigis kolmes mõistatuste alaliigis esildub tegelaskujude või teemade järgi rühmitades zooaspekt, viidates selgelt inimese kalduvusele kasutada iseendast kõnelemisel iseloomustajana loomi.

Artiklis analüüsin ühe või teise elusolendi väljendumise viise konkreetses mõistatuse alaliigis. Loomade esinemissageduse iseloomustamiseks ainehulgas kasutan statistilist meetodit. Põhjusi, miks on loomalembus ja zoonüümide rohkus omane mõistatuste kolmele tänapäeval levinuimale alaliigile, võib olla erinevaid, kuid oluline on pidada silmas nüüdisajal peaasjalikult meelelahutuslike eesmärkidega mõistatamise osatähtsust laste folkloorirepertuaaris. (Seda rahvaluule väikevormi oma rohketes alaliikides on lastefolkloorina käsitlenud paljud tuntud uurijad, vt nt Opie \& Opie 1967, McDowell 1979, Virtanen 1984, Lipponen 1988 jpt.) Nii nagu lastele suunatud kirjanduses, filmides ja näidendites, nii on ka folklooris loom tegelaste kasutamine inimühiskonna metafooride ja sümbolitena kultuuripädevuse omandamise ülilevinud võte.

Uurimuse tekstinäited pärinevad internetiandmebaasidest "Eesti keerdküsimused" (www.folklore.ee/Keerdkys, vt Voolaid 2004), "Eesti (liit)sõnamängud" (www.folklore.ee/Sonamang, vt Voolaid 2003) ja "Eesti piltmõistatused" (www.folklore.ee/ Reebus, vt Voolaid 2002).

\section{Loomariigi esindajad eesti keerdküsimustes ja zooabsurdsus}

Küsisõnalise või küsisõnaühendilise algusvormeliga keerdküsimustes moodustavad tegelaskujude järgi kõige suurema sisulis-temaatilise alajaotuse loomariigi esindajad, kelle seas leidub tegelasi eksootilistest elevantidest tülikate lutikateni. (Eksootiliste ja kodumaiste loomade esinemust eesti keerdküsimuste andmebaasi ainehulgas kirjeldavad joonised 1 ja 2.) Mõistatuste žanrispetsiifika eeldab liiasusrikkeid, mida tajutakse absurdina. Üldjoontes võib loomadega seotud keerdküsimusi liigitada zooabsurdi hulka, mida on eesti paröömikas uurinud Arvo Krikmann (1992). A. Krikmanni järgi omistatakse zooabsurdides klassilisel, liigilisel, liigilis-soolisel vm täpsusastmel terminiga määratletud loomale tunnuseid, mida neil pole (kuid on olemas mõnedel muudel loomadel), näiteks "valesid" värve, enamasti aga olematuid kehaosi (jäsemeid, meeleelundeid) ning füsioloogilisi funktsioone ja võimeid (nt elada ja liikuda teatavates keskkondades, poegida), või siis tehakse katseid saada "valelt" loomalt mõnda kasulikku produkti (villa, piima) või sooritatakse loomadega muid totraid manipulatsioone (ibid: 672). Iseäranis manipuleeritakse loomadega keerdküsimustes, andes neile tegelikkuses olematuid omadusi. 
1. Absurdil põhinevad elevandinaljad ehk elevandiküsimused on suurimloomtegelastega pärimusrühm Eestis (umbes 50 tüüpi ja 850 varianti), mida iseloomustab lai rahvusvaheline tuntus. Need naljad said alguse 1960. aastate alul USAs (Cray \& Eisenberg Herzog 1967: 27), kus elevandinaljad (elephant jokes) kuulusid 17-20-aastaste repertuaari, moodustades Ameerika linnafolkloori (poploori) olulise osa. Ameerika pinnalt jõudsid elevandiküsimused ajalehtede, raadio ja TV vahendusel ülikiiresti kõikjale, sealhulgas Soome (Virtanen 1984: 75) ning levisid nähtavasti Soome kaudu ka Eestisse. Eesti vanimad elevandinaljade üleskirjutused pärinevad aastast 1974 üliõpilaskogujalt M. Laoselt:

A. Kuidas läheb elevant Zaporožetsisse? - Teeb ukse lahti ja istub sisse.

B. Kuidas läheb teine elevant Zaporožetsisse? - Teeb teise ukse lahti ja istub sisse.

C. Kuidas läheb kolmas elevant Zaporožetsisse? - Kuna Zaporožetsil rohkem uksi ei ole, siis tõstab ta lihtsalt esimese elevandi välja ja istub tema asemele.

D. Millal on teine ja kolmas elevant Zaporožetsis? - Siis kui esimene elevant on Zaporožetsist väljas.

E. Millal on teine ja kolmas elevant kõrtsis? - Siis kui Zaporožets on kõrtsi ukse ees (KKI 64: 631-632 (51-55)).

Elevandinaljad on trikiga küsimused, millele vastamiseks on vajalik nende varasem tundmine, esmakordsel kuulmisel on neile võimatu õiget vastust anda. Ühelt poolt rajaneb vastus traditsioonil (vaevalt oskab neile õigesti vastata inimene, kes nalju enne kuulnud pole) ning teiselt poolt apelleerib teatud mõtlemistasemele, absurdse olukorra tajumisele naljakana. Kui näiteks 6 -aastasele esitada levinud küsimusejada A. Mitme liigutusega saab panna elevandi külmkappi? - Kolmega: uks lahti, elevant sisse, uks kinni. B. Mitme liigutusega saab panna kaelkirjaku külmkappi? - Neljaga: uks lahti, elevant välja, kaelkirjak sisse, uks kinni. C. Kes võidab võidujooksu, elevant või kaelkirjak? - Elevant, sest kaelkirjak on alles külmkapis (RKM, KP 34, 622 (8-10)), on tema mõtlemisvõime liiga realistlik, mistõttu elevant on tema silmis lihtsalt nii suur loom, et ei mahu külmkappi ja kõik.

Enamik elevandinalju põhineb kuulajate eksiteele viimisel, ebaloogilisel järeldusel või vastuoludest tuleneval situatsiooni absurdsusel. Joseph Boskini järgi esineb elevant kui koomiline motiiv metafoorina, mida saab tõlgendada nii maagilise kui ka jõu ja tugevuse sümbolina (Boskin 1997: 62). Kuigi inimestele on omane hirm hiiglaslike mõõtmete ja üleloomulike võimete ees, ollakse ühtlasi võlutud elevandi kohmakatest (vaevalistest, rasketest, tülikatest) liigutustest ning rakendatakse neid looma omadusi absurdse ja tõekauge olukorra loomisel. Just absurditunnetusele on üles ehitatud tekstid, kus vaata- 
mata kogukusele jätkub elevandil jõudu ületada loodusseadusi ja ronida puu otsa, esitada akrobaatilisi trikke ja pugeda külmikusse.

A. Miks on elevandil silmad punased? - Selleks, et ennast kirsipuu otsa hästi ära peita.

B. Kas sa oled kunagi näinud elevanti kirsipuu otsas? [- Ei. -] No näed nü̈̈d, kui hästi ta ennast sinna ära peitis (RKM, KP 11, 556 (14cd)) jne.

Ühtlasi viitab J. Boskin Roger Abrahamsi ja Alan Dundese 1969. aastal ilmunud ühisartiklile "On Elephantasy and Elephanticide", milles autorite psühhoanalüütilise interpreteeringu järgi sümboliseerisid elevandid oma korpulentsuses 1960. aastate Ameerikas neegrite kodanikuõiguste aktualiseerumist (samas, lk 62). Eesti elevandinaljades ei ole sellised rassistlikud tagamaad tajutavad.

Münchhausenliku absurdiloogika järgi saavad elevandid puu otsa nii, et külvavad seemne maha, istuvad sellele peale ja ootavad, kuni puu suureks kasvab. Samast loogikast lähtuvalt saavad nad puu otsast alla, kui istuvad lehe peale ja ootavad sügist, et siis koos lehega maha liuelda (RKM II 395, 99 (33)).

Sinised sokid on elevandil jalas sel lihtsal põhjusel, et punased said märjaks (RKM II 324, 92 (1)). Küsimustest nähtub nii mõnigi kord triviaalne loogika: elevandid ei lenda sellepärast, et neil pole tiibu (RKM, KP 7, 23 (12)). Vastaja võiks juba eos teada, et hiire matustele lähevad nad sellepärast, et hiir on surnud (RKM, KP 36, 69 (3)). Kui tekib küsimus, kuidas aru saada, kas elevant on voodi all või kas jõehobu on pumbajaamas, siis vastused on "triviaalsed". Esimesel juhul on voodi lae all: Kuidas saad teada, et elevant on voodi all? Voodi on lae all (RKM, KP 19, 141 (2)). Teisel juhul ei tule kraanist vett: Kuidas saad aru, et jõehobu on pumbajaamas? Kraanist ei tule vett (RKM, KP 31, 58 (5)).

Eesti elevandiküsimustes esinevad kõrval-ja asendustegelastena juba eespool mainitud kaelkirjak, jõehobu, aga ka krokodill.

Miks on neljapäeviti ohtlik džunglis käia? - Elevandid harjutavad langevarjuga hüppamist. Miks on krokodill lapik? - Ta käis neljapäeval džunglis jalutamas (RKM, KP 10, $93(3,6))$.

Levinud võte keerdküsimustes (nagu ka kõnekäändudes, anekdootides, piltmõistatustes ja mujal) on elevandi vm suure neljajalgse vastandamine loomariigi mõnele väga väikesele isendile, nagu hiir või sääsk.

Millal võib hiir rohkem kaaluda kui elevant? - Kui kaal on rikkis (RKM, KP 24, 72 (67)). 
Miks elevant on sä̈̈se pulmas? - Sest nad abielluvad (RKM, KP 12, 435 (26)).

Vanasõnade hulgas esineb vastandav motiiv kolmest rahvaehtsast variandist koosnevas (kirjandusmõjulises) tüübis EV 3869 Ära tii kirbust elevanti. Samalaadsel väikese ja suure opositsioonil põhineb ka tuntud fraseologism sääsest elevanti tegema, sääsest härga tegema tähenduses 'tähtsusetut asja tähtsana esitama, liialdama' (Õim 2000: 471). Meie fraseologismide hulgas on elevant siiski haruldane tegelane. Selle tõestuseks leidub eesti kõnekäändude ja fraseologismide andmebaasis vaid kuus tüüpi: lisaks eelnimetatule justkui elevant portselanipoes, magab nagu elevant puu najal, osta elevant ära, suur nagu elevant ja täis nagu templielevant (EKFA). Elevant kõrva peale astunud on tüübi karu kõrva peale astunud allvariant.

2. Allvariant elevant ja teised eksootilised loomad on kogu eesti folkloori kontekstis kõige võimsamalt esindatud just keerdküsimustes (ja kohe seejärel nähtavasti piltmõistatustes). Meie tavamõistatustes puudub elevant täiesti, küll aga leiame tüübi EM 1454 (Nigiseb ja nagiseb, ilmaski üle aja ei saa? Äke) 98 rahvaehtsa variandi seas ühe mõistatusteksti, milles küsimuspooles on kasutatud võrdlusvahendina kaamelit: Küirakas kui kaamel, ei saa muidu üle aja kui aita? - Äke, kui tõmmata keskelt kokku, on küirakas (üles kirjutatud 1937. aastal Laiuselt). Eesli kohta leidub eesti tavamõistatuste hulgas aga piiblimõjuline tüüp, EM 2120 - Sündü, olõ-õi' ristet, kuuli ar', jummalarmu olõ-õi' võtnu, a kand eloiä jumalat säläh? - Eesli.

Eesti keerdküsimustes on peale elevandi eksootiliste loomadena favoriidid ka näiteks jõehobu, lõvi, kaamel ja eesel, kellele omistatakse inimeste omadusi ja võimeid, inimest võrreldakse aga loomaga.

Miks lõvi ei saa loomaaias magada? - Sest päeval räägivad ahvid anekdoote ja öösel kaelkirjakud naeravad (RKM, KP 36, 62 (2)).

Mis vahe on orjal ja lõvil? - Ori laseb kätt ôlal hoida, kuid lõvi ei lase (RKM, KP 19, 62 ja 64 (13)).

Mis vahe on kaamelil ja inimesel? - Kaamel võib nädal aega ilma joomata käia, aga inimene võib nädal otsa ilma käimata juua (RKM, KP 18, 357 (54)).

Miks kaamel ei söö vatti? - Ta ei taha topiseks saada (RKM, KP 52, 350 (6)).

Mis vahe on eeslil ja inimesel? - Inimene võib eesliks saada, aga eesel inimeseks ei või (RKM, KP 18, 647 (50)). 


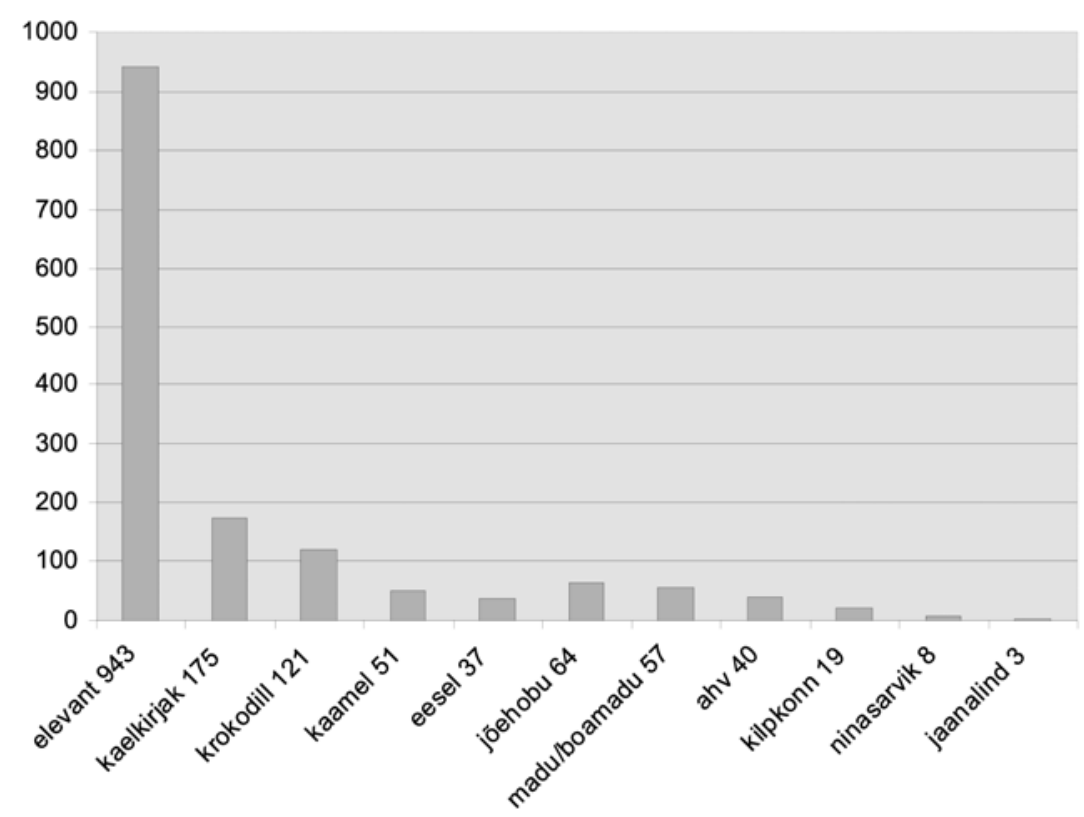

Joonis 1. Eksootilised loomad (üldarv 1518) andmebaasis "Eesti keerdküsimused" (arvesse on võetud zoonüümide esinemist nii tekstide küsimus- kui ka vastuspooles).

Kõigis nimetatud tekstides on loomad projitseeritud inimeste maailmale. Loetelu esimeses küsimuses on loomaaeda kujutatud inimmaailma mudelina, kus erinevad loomad võivad sümboliseerida erisugustest inimestest koosnevat maailma. Oma iseloomult lustlikud ja kiire taibuga ahvid on võimelised vestma anekdoote, mille peale pikkade juhtmetega kaelkirjakud (motiveeritud kaelkirjaku füüsilisest tunnusest - pikast kaelast) reageerivad tuntava hilinemisega, naerdes kuuldu üle alles öösel, segades nõnda ülejäänud elanikkonna (kelle sümboliks on lõvi) und. Võrdluseks sobivad nii positiivsed kui ka negatiivsed loomadega seotud kujutelmad, kasutatakse juurdunud kujundlikke stereotüüpe (nt lõvi sümboliseerib väärikust ja sõltumatust, mis ei pruugi olla iga inimese vältimatu omadus; eesli ja inimese võrdlemisaluseks on rumalus. Keerdküsimuse ajendiks on vaikimisi olnud ilmselt tuntud eesti kõnekäänd rumal kui eesel. Karmides kõrbetingimustes ilma joomata pikka aega toime tulev kaamel vastandub teravalt inimesele, kes on pidevas alkoholijanus. Niisugune inimese ja looma võrdlemine iseloomustab tihtipeale keerdküsimuste zoodiskursust, aga siinkohal tuleb märkida, et elusloodus, eelkõige metsloomad ja linnud esinevad võrdlusvahendina kõige sagedamini kogu eesti fraseoloogias ja kujundkõnes (vt Õim 2003: 86-87). 
3. Eksootiliste loomade kõrval on keerdküsimustes oluline osa ka pika ajalooga koduloomadel koeral ja kassil, seal, hobusel, lehmal jt pikaajalistel inimkooslejail, kelle iseloomustamisel on püütud žanriomaselt lähtuda huumoriperspektiivist. Loomad võivad olla absurdolukorras aktiivsed tegutsejad või sattuda passiivsete olenditena ebareaalsesse olukorda.

Miks koeral raha ei ole? - Sest tal pole rahakotti (RKM II 387, 473 (13)).

Milline peab olema koera peremees, et oma koera õpetada? - Ta peab olema targem kui koer (RKM, KP 9, 581 (6)).

Mis on ühist koeral ja peremehel? - Mõlemad liputavad perenaise ees (RKM, KP 22, 434 (5)).

Mis on koeral ja kirbul vahet? - Kirp koera selga läheb, aga koer kirbu selga ei lähe (RKM, KP 40, 313 (22)).

Mis on ühist lapsel ja koeral? - Mõlemad hauguvad (RKM, KP 13, 129 (13)).

Kuidas saab teha karjakoerast buldogi? - Saba ära lõigata ja nägu üles lü̈̈a (RKM, KP 28, 169 (5)).

Mida peab tegema, et koer ei hauguks autos tagaistmel? - Koer tuleb esiistmele panna (RKM, KP 11, 409 (10)).

Missugune vahe on kassi elu ja vorsti vahel? - Kassi elul on üks ots, vorstil on aga kaks otsa (RKM, KP 20, 285/286 (9)).

Mida ühist on lollil ja seal? - Mõlemad on lollid (RKM, KP 41, 255 (2)).

Mis vahet on knopkal ja hobusel? - Hobuse selga istud, aga knopka otsa vist mitte (RKM, KP 37, 252 (2)).

Mis värvi on keisri valge hobune? - Valge (RKM, KP 23, 377 (29)).

Missugune hobune näeb taha niisama hästi kui ette? - Pime hobune (RKM, KP 10, 242 ja $245(22)$ ).

Jooniselt 2 ilmneb, et esinemissageduselt (arvestatud on zoonüümide esinemist nii küsimus- kui ka vastuspooles, mistõttu sama teksti piires võib sama loomanimi korduda) on kodumaistest loomadest ülekaalukalt esimene koer peaaegu 800 esinemiskorraga, talle järgnevad 2) hobune (590 esinemiskorda), 3) kana (446), 4) kirp (342), 5) siil (339) ja 6) kurg (256). Üllatuslikult on kass, tänapäeva üks populaarseimaid lemmikloomi, esindatud keerdküsimustes vaid 102 korral. Lühivormižanriti on loomade esinemus erinev: ka eesti vanasõna- 


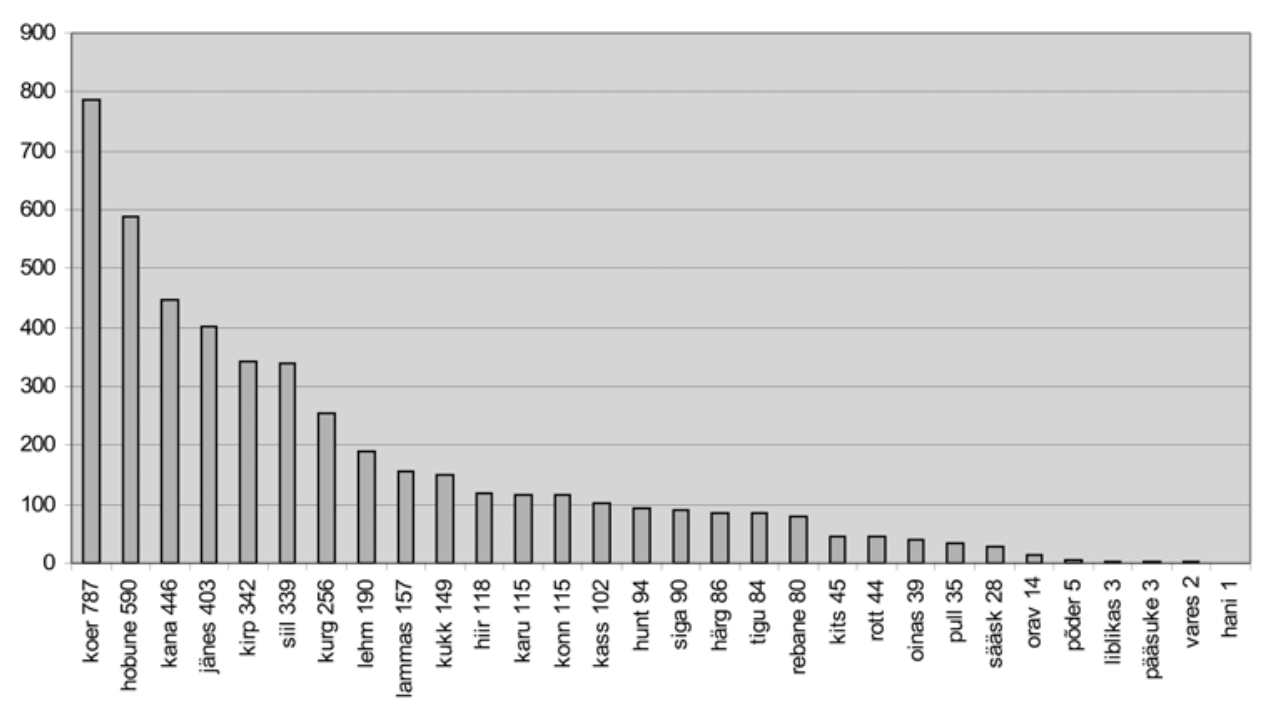

Joonis 2. Kodumaised zooloogilised olendid (üldarv 4762) andmebaasis "Eesti keerdküsimused" (arvesse on võetud zoonimede esinemist nii tekstide küsimus- kui ka vastuspooles).

des moodustavad suursoosikute kolmiku koer, hobune ja veis, kellele järgnevad 4) kana/kukk, 5) hunt, 6) siga, 7) kass ja 8) lammas/oinas (vt Krikmann 1999: 56). Eesti kõnekäändude sagedusjärjestused puuduvad, kuid andmebaasi EKFA põhjal saab öelda, et koera ja kassi vahekord on küll eesti kujundkõnes vastupidine kui nt keerdküsimustes või vanasõnades: 70 kõnekäänutüübis on esindatud koer, samal ajal on kassiga tüüpide hulk kolm korda suurem ehk 210 .

4. Koduloomade kõrval figureerivad keerdküsimustes ka Eestis elavad metsloomad siil, karu, jänes (võib esineda koduloomana eelmise tüübi all), rebane, kes võivad küsimustes väljendada väga erinevaid tähendusi ning jätavad küsijale võimaluse eksitada vastajat mitmemõttelisustega.

Kas võib istuda siilile? - Jah võib, kui siil on pöetud või perse pole enda oma (RKM, KP 42, 156 (35)).

Kuidas isasiil ja emasiil armastavad? - Ettevaatlikult (RKM, KP 40, 282 (3)).

Mis on ühist siilil ja kuusel? - Mõlemal on lugematul arvul okkaid (RKM, KP 24, 557 (35)).

Mis saab, kui ristata siil ussiga? - Kolm meetrit okastraati (RKM, KP 43, $533(28)$ ). 
Mis vahe on emasel siilil ja isasel siilil? - Isasel on üks okas rohkem (RKM, KP 40, 313 (25)).

Kas võib karu lehmaga ristata? - Mitte üksnes ei või, vaid peab, sest hübriid annab ju suviti piima ja imeb talvel käppa (RKM, KP 24, 281 (23)).

Kuidas pü̈̈da karu? - Tuleb puu külge panna polt ja ots meega kokku teha. Karu lutsutab kuni polt tuleb tagumikust välja, siis keeratakse mutter otsa (RKM, KP 28, $171(2))$.

Kui kaugele jookseb jänes metsa? - Kuni poole metsani, siis hakkab ta metsast välja jooksma (RKM, KP 38, 199 (10)).

Kuidas saab jänest pü̈̈da? - Teed põõsa taga porgandi häält (RKM, KP $20,82(20))$.

Kus on kõige rohkem jäneseid? - Ühissõidukites: piletita sõitjad (RKM, KP 6, $361(25)$ ).

Miks jookseb jänes üle mäe? - Sest mäe alt ei saa joosta (RKM, KP 8, 219 (2)).

Mis on jänese ja propagandisti vahe? - Jänes ei lobise (RKM, KP 42, $155(80))$.

Mis on palju puid ja vähe liha? - Jänes metsas (RKM, KP 34, 622(6)).

Millal ei ole rebane enam rebane? - Siis, kui neid on kaks, siis nad on rebased (RKM, KP 44, 104 (6)).

Loomateemalised keerdküsimused on oma sisult (temaatikalt) väga heterogeensed, nt viimane küsimus mõjub alttõmbamisküsimusena, sest kui neid on kaks: sel juhul on ju rebased. Samas võiks sõna "rebane" asendada ükskõik millise teise loomaga või üldse mitte loomaga.

5. Keerdküsimustes on esindatud ka kahepaiksed (konnad, sisalikud), roomajad ja kalad.

Kuidas saad aru, et konn on täis puhutud? - Proovi nõelaga järgi (RKM, KP 31, $58(3)$ ).

Kuidas hoida konna kure eest? - Ütlete konnale, kui kurg tuleb (RKM, KP 14, 357 (2)).

Mida teeb sisalik oma sabaga? - Veab järel (RKM, KP 43, 257 (55)).

Milline loom kiindub inimesesse kõige rohkem? - Kaan (RKM, KP 43, 120 (7)). 
Kas kalad higistavad? - Muidugi, muidu poleks merevesi soolane (RKM, KP 44, 113 (12)).

Miks on lest lame? - Magas vaalaga. Miks on ahvenal silmad punnis? Ta nägi seda pealt (RKM, KP 13, 409 (1)).

Milliseid kalu on vees kõige rohkem? - Elavaid kalu (RKM, KP 34, 498 (44)).

Missugune kala ei uju? - Praetud (RKM, KP 32, 187 (23)).

Kuidas saad kala soomustest puhtaks? - Paned kümneks päevaks prügikasti juurde. (RKM, KP 27, 31 (3))

Miks poes kala pole? - Kala pole lits, teda nii kergesti ei pü̈̈a! (RKM, KP $24,554(13))$

Rikkalikult on esindatud mitmesugused putukad. Näiteks lutikaid kujutatakse keerdküsimustes väga sageli nõukogude ühiskonna olmelise püsikomponendina, mistõttu on nad hästi sobinud omaagsese sotsiaalkriitilise huumoriga.

Kas lutikad hiilgavad? - Ei, sest muidu oleks terve Venemaa valge (RKM, KP 25, 79 (4)).

Kas lutikad võivad teha revolutsiooni? - Ja, sest neis voolab töörahva veri (RKM, KP 24, 556 (30)).

Kuidas hävitada lutikaid? - Tapetseerige kõik seinad loteriipiletitega ja lutikad naeravad ennast lõhki (RKM, KP 26, 317 (40)).

Mis saaks, kui lutikad sisaldaksid fosforit? - Venemaal oleks ööd valged (RKM, KP 19, $471(25)$ ).

Miks on madratsid triibulised? - Et lutikad liikluseeskirju ei rikuks (RKM, KP 11, 585 (16)).

Lutikatest ühiskondliku kriitika poolest tunduvalt neutraalsema sõnumi kandjad on keerdküsimustekstides näiteks kärbsed, mesilased, kirbud ja täid.

Kuidas kärbseid tuppa kutsutakse? - Neid ei kutsuta, nad tulevad ise (RKM, KP 23, 259 (51)).

Mis ühist on direktoril ja kärbsel? - Mõlemaid tapetakse ajalehega (RKM, KP 19, $771(1))$.

Kes on mesilane? - Tavaline kärbes, kellele on grammofoninõel tagumikku pistetud (RKM, KP 34, 498 (51)). 
Miks on kõik kirbud mustad? - Nad leinavad oma tapetud sugulasi (RKM, $\mathrm{KP} 16,373(2))$.

Kellel pole täisid? - Täil (RKM, KP 23, 472 (107)).

Kes käib üle mõistuse? - Täi (RKM, KP 37, 11 (13)).

6. Keerdküsimustes väljendatav erootiline mõõde avaldub just inimmeeles välja kujunenud stereotüüpsetes paralleelides - kahe inimsugupoole võrdlemisel loomariigi emas- ja isasisendiga. Tavapärase võttena omistatakse loomadele inimeste omadusi ja võimeid ning ka vastupidi. Niisuguses antropomorfistlikus/zoomorfistlikus kujundikasutuses on inimest tihtipeale võrreldud loomaga. Eriti silmatorkav on see võrdlus seksuaalset värvingut kandvates küsimustes näiteks kukest ja kanast, pullist ja lehmast, kuldist ja emisest. Ühelt poolt projitseeritakse antropomorfistlike kujundvõtete kaudu inimlikud psüühilised omadused loomadele-lindudele:

Mida mõtles kana, kui auto alla jäi? - No naabri kukk see küll ei olnud (RKM, KP 43, $532(6)$ ).

A. Mida mõtleb kukk, kes kana taga ajab? - Kui muud ei saa, siis sooja ikka saab.

B. Mida mõtleb kana, kes kuke eest jookseb? - Kas ma ehk liiga kiiresti ei jookse.

C. Mida mõtleb kana, kes seda pealt vaatab? - Küll on loll kukk, mina olen ju lähemal (RKM, KP 42, 204 (11)).

Mida mõtleb kukk, kui näeb kanu riidlemas? - Kumb neist jälle ilma on jäänud? (RKM, KP 44, 104 (2)).

Miks kukk nii rõõmsalt laulab? - Sest tal on palju naisi ja mitte ühtegi ämma (RKM, KP 28, 52 (15)).

Teisalt on zoomorfistlike võtete kaudu aimatav kana ja kukk kui naise ja mehe võrdkujud:

Miks piiluvad kuked lihapoe aknast sisse? - Loodavad alasti kanu näha (RKM, KP 19, $532(26)$ ).

Miks pole kukel käsi? - Sest kanal pole pükse (RKM, KP 29, 261 (4)).

Miks kanal pole pükse? - Sest kukel pole käsi (RKM, KP 6, 456 (2)).

Miks paneb kult silmad kinni, kui ta emise juurde läheb? - Tal on häbi, et armastab siga (RKM, KP 11, 554 (9)).

Antropomorfistliku kujundiprojektsiooni kaudu oleks justkui lihtsam esile tuua keerdküsimuse allapoole vööd suunatud nalja tuumideed. Sellised üksused on 
konfigureeritud tihti nii, et küsimus näib väliselt süütu, aidates võimendada vastuses järgnevat "seksuaalset lööki”. Kogu seda teemakategooriat võib käsitleda näiteks soouurimuslikust aspektist, sest vaadeldavas aineses on esindatud paralleelselt nii meeste kui ka naiste identiteedikategooriad. Sedalaadi keerdküsimusmaterjali võib vaadelda kindlasti kõrvuti mehe-naise suhtevõrgustikke ja stereotüüpe käsitleva anekdoodimaterjaliga. Eelmainitud kahes sisulõikes kuuluvad ka sellised loomtegelastega küsimused seksuaalhuumori alale.

\section{Liitsõnamängud, iseäranis zooloogilistel kinnismetafooridel põhinevad liitsõnamängud}

Folkloori ja keele piirimaadel asuvatel liitsõnamängudel on enim vormilisi kokkupuutepunkte keerdküsimustega, mis võivad samuti alata küsisõnaga missugune. Kahe pealtnäha sarnase mõistatuse alaliigi erinevus seisneb aga loomispõhimõtetes. Kui keerdküsimuste puhul nõuab vastus otsest omadussõna (Milline on Itaalia sõdur, kui ta kukub Punasesse merre? - Märg), siis liitsõnamängu harjumuspäraseks vastuseks on keeles tavamõisteteks saanud kahetüvelised liitnimisõnad kui keeles sügavalt juurdunud kinnismetafoorid (ka frozen metaphors - 'külmunud tardunud metafoorid' (nt Gibbs 1994: 123), dead metaphors - 'surnud metafoorid' (nt Lakoff \& Johnson 1999: 119) või kulunud metafoorid (nt Merilai 2003: 149)), mille kujundlikkus on ajapikku nihkunud tagaplaanile ning mida keelekasutaja ei pruugigi tajuda: püssikirp, koeranael, masinahunt, võhumõõk, sukasilm, veesilm, tassikõrv, kotisuu, jõesuu, adralusikas, laevanina, puusüda, puusärk, õunasüda, jne. Liitsõnamängud eeldavad seega, et leidub mingi predikaat (omadus, tegevus vms), mis assotsieerub sõna otsese tähendusega väga tugevasti, surnudmetafoorse tähendusega aga mitte (või ka vastupidi) (Krikmann 1997: 19).

Küsimus missugune? juhib vastaja mõtted omadussõnale, ent pärast paarile liitsõnamängulisele mõistatusele vastamist omandab ta kergesti struktuuriskeemi ja loomisvõtted, mistõttu jõuab ta edasiste õigete vastusteni juba tuginedes oma keele ja kujundkõne kasutamise kogemustele.

Mõningal juhul võib liitsõnamängulise mõistatuse algusvormelina esineda ka nt küsisõna kelle? (Kelle keppi ei taha keegi kanda? - Sandi keppi). Säärasel juhul on vastuses genitiivse liitsõna asemel (grammatiliselt lahku kirjutatud) omamissuhtele viitav genitiivne sõnaühend.

Stereotüüpset missugune?-algusmalli rikuvad ka küsimused, mis algavad alalütleva vormeliga kellel? / millel? ning eeldavad vastajalt verbi olema laiendina omaja väljendamiseks alalütlevat käänet (nt Kellel millel on jalad all, aga siiski ei kõnni? - Sängil, pingil, toolil, laual). Niisugusel juhul ei saagi anda 
grammatiliselt korrektset vastust liitsõnana, ent vastuses on kujund olemas. Mõnikord on ka alalütlevale vormile lisatud seletuseks liitsõnaline kinnismetafoor: Kel on kõige rohkem kapju? - Varsal, varsakabjad; Kel on kõige suurem koorem? - Penil, penikoorem.

Erandina võib vastuses asuda liitsõna põhisõna rolli ka sellega samakõlaline lihtsõna (sagedamini võõrsõna) lõpuosa ning siis on küsimuses ja vastuses tegemist eritähenduslike mõistetega: Missugune tross pü̈̈ab kalu? - Albatross; Missugused pullid ei ela? - Ampullid. Siia kuulub ka tegelikult mängimine $k o n d$-liitega, mille ainsuse omastav ja sellest moodustatud vormid annavad konna ja konnad: Missugused konnad ei krooksu? - Ülikonnad.

Piirjuhtudel erineb vastussõna küsimuse substantiivist vaid ühe-kahe selle ette lisatud tähe hääliku poolest: Milliseid rotte sööb inimene? - Sprotte.

Teinekord ei pruugi kirjalikus vormis sõna kattuda küsimuses ja vastuses täht-tähelt: Millist tilli kardavad lapsed kõige rohkem? - Krokodilli; Missugune koi räägib? - Papagoi; Missugused krahvid ei sure? - Paragrahvid. Kuna sõnalise folkloori varasem põhikäive oli suuline, ei seganud niisuguste mitteliitsõnalise vastusega kvaasiliitsõnamängude loomist ka seik, et küsimuses ja vastuses korduvad häälduslikult enam-vähem identsed osised võisid osutuda kirjapildi poolest erinevaks. Suulises esituses on selliste homonüümide kirjaja häälduspildi väike erinevus vaevu märgatav. See diferents on probleemiks keeltes (nt inglise keeles), kus kirjapilt ei järgi häälikulist koostist. Tuntud huumoriuurija Salvatore Attardo (1994: 109-111) on juhtinud tähelepanu ingliskeelsetele kalambuuridele, millest mõned on efektsed just kirjutatult, teised jälle ainult öeldult.

Liitsõnamängu küsimus konstrueeritakse liitsõna põhiosa traditsioonilise funktsiooni järgi. Vastuseks on liitsõna, kus põhisõna esmane funktsioon nihkub tagaplaanile. Vastaja juhtimiseks sõna otseselt tähenduselt metafoorse juurde kasutatakse küsimuses tavapäraselt (ent mitte alati) eitavat verbivormi. Jaatava verbivormi puhul eeldatatakse samuti, et põhisõnal tegelikult küsimuses esitatud funktsioon puudub (Missugune hiir lendab? - Nahkhiir) või sageli väljendatakse karitiivsust ilmaütleva käände kaudu (Mis rott jäeb ilma varanduseta? - Pankrot. Missugune jalg on ilma kehata? - Lauajalg).

Niisiis rajanevad näiteks põhisõnaga kass loodud liitsõnamängud kassi loomuomastel funktsioonidel, mida küsimuses eitatakse ning mida õige vastusena oodatava liitsõna surnudmetafoorsel referendil tõepoolest ei ole:

Missugune kass ei näu? (Kassid näuguvad.) - Pajukass.

Missugune kass ei armasta piima? (Kassid armastavad piima.) - Vihmakass.

Milline kass lendab? (Kassid ei lenda.) - Vihmakass.

Missugune kass ei söö hiiri? (Kassid söövad hiiri.) - Kaevukass. 
Liitsõnamängu põhimõttel loodud mõistatused ei lase end enamasti võõrkeelde tõlkida. Kinnisfraasiliste žanride, st üsna muutumatu sõnastuse ja sisuga žanride tekstuur (milleks on verbaalsetes žanrides keel, konkreetsed foneemid ja morfeemid, mida kasutatakse) võib peaaegu välistada tõlkimise võimaluse (Dundes 2002: 74). Liitsõnamängud illustreerivad seda väidet ilmekalt; nad sõltuvad niivõrd oma koetisest, et levivad harva ühest keelelisest kogukonnast teise. Kui vormi ja sisu ühtsusest mitte hoolida, saab liitsõnamänguteksti põhimõtteliselt sõnasõnalt tõlkida küll, ent võõrkeeles läheb kaduma selle sisu ja mõte, nagu näiteks tuntud liitsõnamängus Missugune hiir lendab? - Nahkhiir, mille ingliskeelne tähendus on 'Which mouse can fly? - The bat'. Eesti keeles kõlab väga totra ja ebaloogilisena nt järgmine soomekeelne liitsõnamängu põhimõttel loodud tekst: Mikä kaali voi syödä jopa sinut? - Shakaali (Lipponen 1995: 193), mille otsetõlge on 'Missugune kapsas võib sinu ära sü̈̈a? - Šaakal'. On muidugi ka universaalseid, eri keeltes sarnaseid liitsõnalisi või genitiivse esikomponendiga metafoore, mille tuum jääb tõlkimisel samaks. Nii näiteks põhineb meie sõnamänguteksti Missugune suu ei räägi? - Kotisuu ingliskeelne folkloorne versioon What has a mouth but does not speak? - A sack suhteliselt sarnasel alusel (kinnistunud metafooril sack('s) mouth). Mõistatuste allžanridest jäävad sageli tõlkimatuteks ka lühendid ja valemid, mille tekstuur on omane kindlale keelele. Samas on huvipakkuv nähtus, kus tõlkimatusefekte kasutatakse nalja saamiseks. Mõlema asjaomase keele tundmine on eelduseks nt idioomide otsetõlgetes või liitsõnade "analüütilistes" tõlgetes keeltesse, kus liitsõnu ei kasutata (nt lause Koer poiss teeb karutükke vene keeles 'Собака мальчик делает медвежие куски', teeklaas 'чайное стекло').

Kui eesti liitsõnamängude produktiivseimaks allikaks on somaatilised metafoorid (nt Missugune hammas ei asu mitte suus? - Naljahammas), siis teine väga tootlik sõnarühm, mille kaudu eesti liitsõnamänge (ja kvaasiliitsõnamänge) tihti üles ehitatakse, on loomanimetused. Alljärgneva näitematerjali hulgas on esitatud zooloogilist põhisõna sisaldavate liitnimisõnadega sõnamängud.

Zooloogiliste kinnismetafooride esinemust näitab joonis 3. Kõige enam on liitsõnamängutüüpe loodud järgmiste põhisõnadega:

konn (101 var)

Missugused konnad ei ela? - Ülikonnad (RKM II 327, 9 (11a) - 1 var).

Missugune konn ei hüppa? - Kilpkonn (RKM I 14, 299 (I, 7) - 11 var).

Missugused konnad ei krooksu? - Ülikonnad (KKI 44, 33 (70) - 78 var).

Missugused konnad on kõige suuremad? - Kihelkonnad (H II 15, 161 (6) - 8 var).

Missuguses konnas elutseb suur kogu inimesi? - Kogukonnas (Lasteleht nr 1 (1904) 16-3 var).

kukk (94 var) 


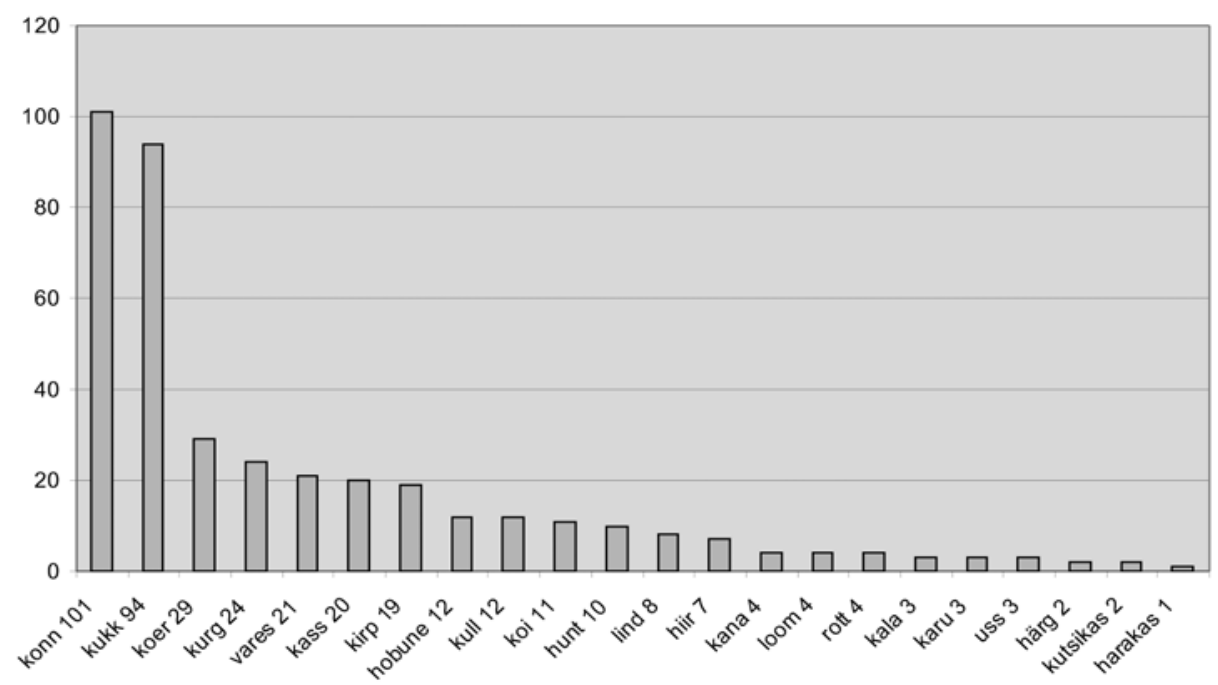

Joonis 3. Loomanimedel põhinevate konstruktsioonide (394 varianti) esinemus eesti liitsõnamängude andmebaasis.

Missugune kukk ei kõlba sü̈̈a? - Kirikukukk (RKM II 263, 372 - 1 var). Missugune kukk käib jahil? - Püssikukk (H IV 8, 351 (152) - 1 var).

Missugune kukk ei laula? - Püssikukk (E 8552 (38) - 61 var).

Kukk on, aga ei lenda? - Kirikutornikukk (Eisen 1913: 73 (556) - 12 var).

Kukk on, aga ei lenda, kikas on, aga ei kire? - Kirikutornikukk (RKM II 24, 474 (140) - 1 var).

Missugusel kukel ei ole harja? - Riiukukel, püssikukel (RKM II 334, 355 (3) - 12 var).

Mis kukk see on, mida keegi ei salli ja mida kõik kardavad? - Punane kukk (tulekahi) (RKM II 293. 586 (332) - 3 var).

Missugusel kukel ei ole naist? - Kirikutornikukel (RKM II 22, 506 (187) 2 var).

koer (29 var)

Missugune koer ei haugu? - Hiirekoer (E 8553 (40) - 29 var).

kurg (24 var)

Mis kurg ei söö ega kõnni? - Adrakurg (RKM II 309, 425 (758) - 1 var).

Missugune kurg ei lenda? - Adrakurg (Meelej nr 19 ja 21 (1885) 97 ja 110 (2) - 23 var).

vares ( 21 var)

Missugune vares ei kraaksu? - Hädavares (RKM II 354, 11 (63) - 3 var). Missugune vares pole lind? - Hädavares (RKM II 334, 230 (82) - 8 var). Millised varesed ei lenda? - Hädavaresed (RKM II 334, 299 (78) - 10 var). 
kass (20 var)

Missugusel kassil pole suud? - Ning pajukassil pole suud (H, R 3, 48 1 var).

Missugune kass pole majaloom? - Vihmakass (H IV 8, 352 (157) - 1 var). Missugune kass ei pü̈̈a hiirt? - Vihmakass (H IV 8, 356 (198) - 1 var).

Mis kass ei söö hiiri? - Kaevukass (RKM II 309, 427 (779) - 1 var).

Missugune kass ei ole hiirekass? - Vihmakass (Eisen 1913: 86 (1111) - 1 var).

Missugune kass ei ole hiirekoer? - Vihmakass (E 8552 (39) - 1 var).

Missugune kass ei söö hiiri? - Valekass (EKRK III 41, 179 - 1 var).

Missugune kass ei näu? - Pajukass (RKM II 334, 567 (18) - 4 var).

Milline kass lendab? - Vihmakass (LR nr 5 (1938) 119 (6) - 4 var).

Missugune kass ei armasta piima? - Vihmakass (Eisen [1914]: 27 (226) 4 var).

Missugune kass ei sure? - Asesõna "kas"(EFA I 12, 52 (7) - 1 var).

kirp (19 var)

Missugust kirpu ei tapeta? - Püssikirpu (H IV 8, 351 (151) - 1 var).

Missugune kirp ei karga? - Püssikirp (E 8551 (25) - 18 var).

hobune (12 var)

Mis tõugu hobune on parim ujuja? - Merehobune (Tähtr (1939) 147 ja 157 (18) - 1 var).

Missugune hobune ei söö kaeru? - Laste mänguhobune (H IV 8, 353 (171) -2 var).

Missuguse hobusega ei sõideta? - Jõehobusega (E 8549 (2) - 5 var).

Missugusel hobusel pole hinge? - Puust hobusel [puuhobusel] (Eisen [1914]: 31 (357) - 4 var).

kull (12 var)

Missugune kull ei mune? - Kohtukull (H IV 8, 343 (172) - 1 var).

Missugune kull ei pü̈̈a kanu? - Kohtukull (E $8^{\circ}$ 4, 20 (38) - 2 var).

Missugune kull on kõige kardetavam? - Kohtukull (Eisen [1914]: 27 (243) -2 var).

Missugune kull ei lenda? - Kohtukull (E 8549 (8) - 7 var).

koi (11 var)

Missugune koi oskab lugeda? - Raamatukoi (RKM, KP 23, 378 (42) - 7 var).

Milline koi õitseb? - Levkoi (LR nr 8 (1938) 191) - 1 var).

Missugune koi räägib? - Papagoi (RKM II 418, 4 (3) - 1 var). 
Missugune koi ei söö auke? - Raamatukoi, ihnuskoi (RKM II 334, 229 (80) -1 var).

Mis koi ei riku riiet-puud? - Ihnuskoi (RKM II 309, 425 (755) - 1 var).

Kõigis ülaltoodud näidetes on zooloogiline olend liitsõna põhilise osana käsitatav teine komponent. Huvitaval kombel esineb ainehulgas põhjaeestilise nimetusega koer konstrueeritud liitsõnu (kus arvatav esimene koduloom esineb põhisõna positsioonis) (päevakoer, hiirekoer, lõukoer), kuid lõunaeesti sõna peni pole vähemalt põhikomponendina liitsõnamänge looma ajendanud. Ent sõnamänguliste mõistatuste hulgas leidub küllalt selliseid, kus loomanimi esineb genitiivse substantiivina täiendosas, ja täiendina figureerib lõunaeestiline peni vähemalt ühes liitsõnas (penikoorem). Sisuliselt genitiivmetafoorsed zooloogilist komponenti sisaldavad keelendid on lisaks veel kukehari, seaharjas, varsakabjad, õngekala, kassikangas, kukekannus, karukell, oinakell, käokell, härjakell, käoking, kassikäpp, hiirekoer, hiirekõrv, kuresaapad, koeranael, pääsusilm, võhumõõ , härjapea). Silmapaistvalt suure osa eelloetletud zooloogilise osisega liitnimisõnadest moodustavad taimenimetused. Vaadeldud ainese põhjal võib samuti väita, et liitsõnaloome põhineb suuresti kodumaistel zoonüümidel, eksootiliste loomanimede osakaal on olematu. Niisugust tendentsi võib seletada liitsõnaloome printsiibiga, kus uued mõisted tekivad esijoones keeles juba varem olemasolevatest sõnatüvedest.

\section{Loomakuju eesti piltmõistatustes}

Nagu terminist piltmõistatused võib järeldada, on neis harjumuspäraselt küsimuseks paberile joonistatud (ja enamasti raamitud) minimalistlik pilt (mille juurde esitatakse suuliselt vaid küsimus mis on pildil?). Vastuseks on pildil oleva nähtuse, eseme, tegevuse, olukorra nimetus või neid kirjeldav lause, mistõttu on neid nimetatud ka visuaalseteks kirjeldavateks mõistatusteks (visual descriptive riddles) (Roemer 1997: 178). Niisiis erinevad reebused selles plaanis otseküsimust sisaldavatest keerdküsimustest, liitsõnamängudest jt mõistatuste alaliikidest ja meenutavad just tavamõistatusi, kuna koosnevad millegi kirjeldusest (küll mitte verbaalsete, vaid graafiliste vahendite abil) ja lahendusnõude lisamine on vaikimisi endastmõistetav.

Mis on pildil?

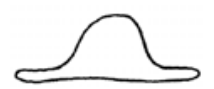

Boamadu, kes on elevandi alla neelanud. 
Vanaaega käsitlevates ajalooteostes on tänapäevaste piltmõistatuste arhailisi analooge peetud sumeri kiilkirja ja muude piltkirjatüüpide ning seega kogu kirjutamiskunsti eelkäijateks, sest tähtis samm kirjutamiskunsti suunas tehti siis, kui inimesed hakkasid kasutama pilte mõne kindla eseme tähistamiseks. Ehkki piltmõistatusi on tuntud sajandeid, said nad populaarseks 1950. aastatel Ameerikas. Ingliskeelne termin droodles pärineb 1953. aastast ameeriklaselt Roger Price'ilt (Price 1953), kes kombineeris sõnad drool ('jampsima, lollitama') ja doodle ('kritseldus'); soome laste seas hakati neid 1970. aastatel nimetama sõnaga toopeli (Kaivola-Bregenhøj 2001: 62).

Piltmõistatuste teemade ja tegelaste ring on lai, inspiratsiooni pakub elu ise. Käesoleva uurimuse kontekstis on huvipakkuv, et vähemalt kolmandikus piltmõistatustes esinevad loomad, keda kohtab ka kahes eesti ainehulgas kõige populaarsemas piltmõistatustüübis (kumbki tüüp koos allvariantidega moodustab piltmõistatuste üldarvust umbes $10 \%$ ):

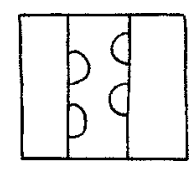

1. Karu ronib puи otsa (RKM, KP 11, 591 (7) - 710 var).

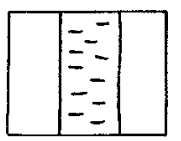

2. Kaelkirjak akna taga (RKM, KP 30, 357 (2a) - 697 var).

Nende kahe (kodumaise karu ja eksootilise kaelkirjaku) piltmõistatuse järgi võib liigitada kogu loomateemalise piltmõistatusmaterjali: 1. Eestis elavad kodu- ja metsloomad, 2. eksootilised loomad. Kui pilt kujutab üksikut loomobjekti, siis joonistatakse äraarvamise hõlbustamiseks olendi iseloomulik tunnus, näiteks:

kaelkirjaku pikk kirju kael

jänese pikad kõrvad

elevandi lont
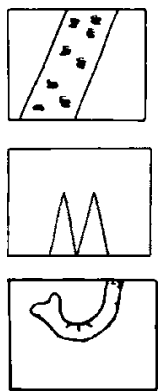
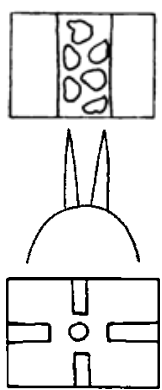
kaameli kü̈̈rud
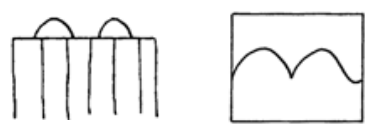

sebra vöödiline karvkate
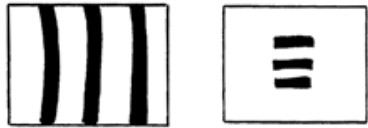

siili okkaline kasukas
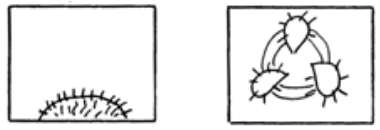

Sageli on loomad inimesele seltsi pakkumas:

kauboi hobuse seljas

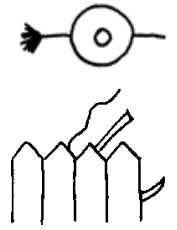

jahimees läheb püssi ja koeraga

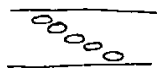

Tarzan pääseb jõe teisele kaldale, kui jookseb üle krokodillide

neli elevanti nuusutavad oma mustanahalist pärisperemeest

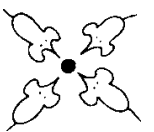

Mõne piltmõistatuse visuaalses küsimuspooles puudub aga igasugune loomale vihjav detail, näiteks:

vanaeit veab kitse, aga ainult nöör mahtus pildile

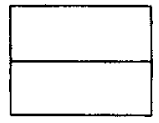

lehm sõi rohtu ja läks koju

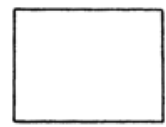

ning et pilt üldse loomaga seondub, ilmneb alles traditsioonilisest vastusest.

Kodumaiste ja eksootiliste loomade esinemusest piltmõistatustes annavad ülevaate joonised 4 ja 5 . 


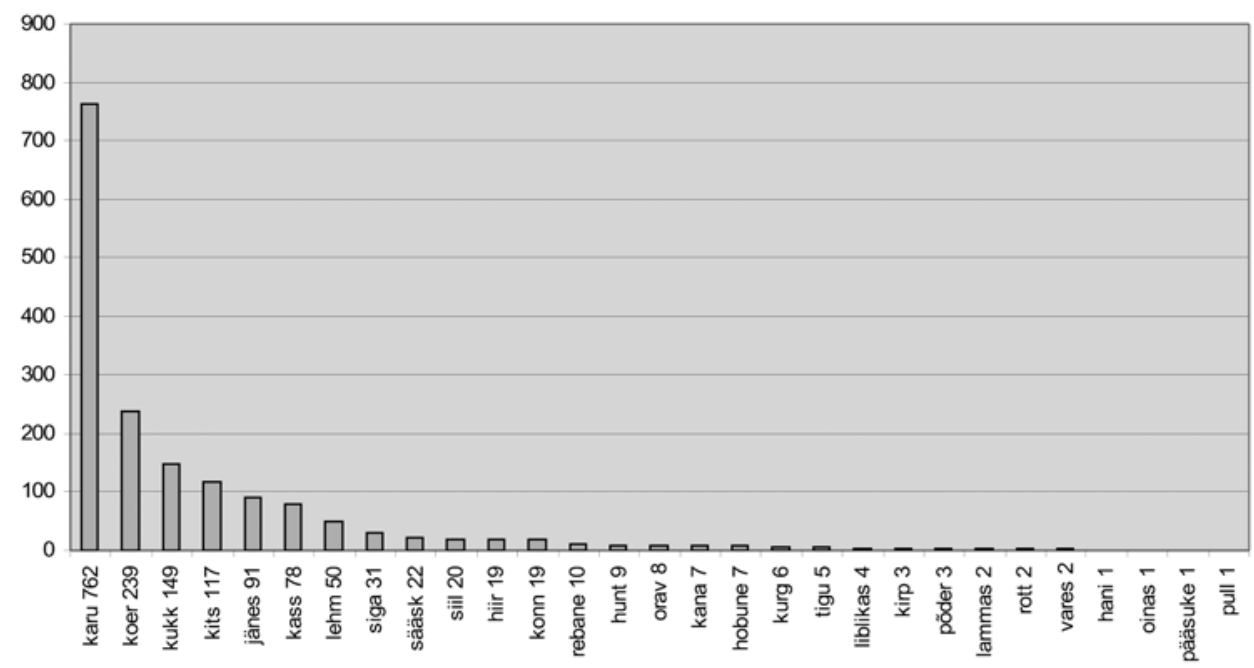

Joonis 4. Kodumaised zooloogilised olendid (üldarv 1669) eesti piltmõistatustes.

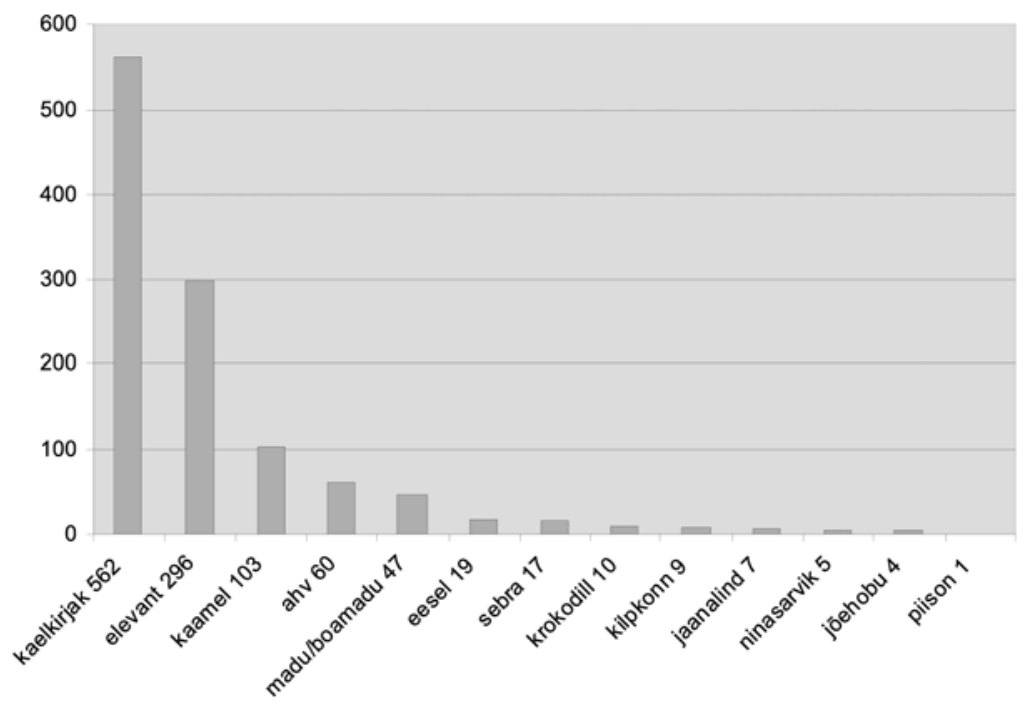

Joonis 5. Eksootilised olendid (üldarv 1140) eesti piltmõistatustes.

\section{Kokkuvõte}

Käesolevas uurimuses keskendusin zooloogilistele isenditele kolmes suuremas mõistatuste (sageli ka perifeeriaks nimetatud) hilistekkelises subžanris: keerdküsimustes, liitsõnamängudes ja piltmõistatustes. Kõigis neis on loomad tegelaskujudena esindatud arvukalt, kuid igaühes väljendab loomaparadigma ise jooni. 
Umbkaudu neljandik eesti keerdküsimustest sisaldab loomanimesid, sarnaselt nt rahvajuttudega (muinasjutt, naljand, anekdoot) või mitmesuguste kunstiliikidega (valm, animafilmid, teatrietendused) on neis loomale antud väga vaba kujundikontekst. Sageli võib kohata antropomorfistlikku personifikatsiooni, kus zooloogilisele olendile projitseeritud inimlikud omadused kanduvad kindlate stereotüüpide funktsioonidesse ning loomad kõnelevad tihtipeale meist endist ja toimivad meie endi võrdkujuna. Erinevaid inimtüüpe kujutavad loomad võimaldavad mõistukõne abil naeruvääristada inimeste ja ühiskonna pahesid. Muudes eesti lühivormides (vanasõnades ja kõnekäändudes) on populaarseimad loomad üldiselt omamaised koduloomad ja -linnud, kuid meie keerdküsimuste levinuimad loomtegelased on hoopis eksootilised (elevant, jõehobu jne). Ühelt poolt on selle põhjuseks rahvusvahelise ainese suur osatähtsus (nt angloameerika kultuuriruumist meieni jõudnud elevandinaljad), ent teisalt on eksootiline võõras folklooritekstides köitev. Olukorrad ja situatsioonid, milles loomad keerdküsimustes (ja ka piltmõistatustes) esinevad, on kaugel reaalsusest, mistõttu laiemalt võib loomadega seonduvat nimetada zooabsurdiks.

Meie liitsõnamängud viitavad eesti keele liitsõnalembusele ning zooloogilised olendid sagedaste liitsõna osistena tõestavad, et asjade, nähtuste ja omaduste nimetamisel liitsõnamoodustuse teel on loomariik olnud inimesele oluline motivaator. Liitsõnamängude moodustusallikaks on enamasti kinnismetafoorsed liitsõnad (nt kohtukull, raamatukoi), mille kujundlikkus on ajapikku nihkunud tagaplaanile. Enamasti on zooloogiline olend liitsõna põhilise osana käsitatav teine komponent (nt päevakoer, hiirekoer, lõukoer), kuid leidub küllalt selliseidki, kus loomanimi esineb genitiivse substantiivina täiendosas (nt penikoorem).

Kolmandik eesti piltmõistatuste ainehulgast kujutab loomariigi esindajaid, kuid populaarseimad loomad näivad olevat need, kelle liigiomased välistunnused sobivad graafiliseks visualiseerimiseks (jänese pikad kõrvad, elevandi lont, kaameli küürud, kaelkirjaku pikk kirju kael, sebra vöödiline nahk) ja neist on hõlbus kujundada traditsiooni.

\section{Arhiiviallikad}

$\mathrm{E}=\mathrm{M}$. J. Eiseni rahvaluulekogu

EKRK = Tartu Ülikooli eesti kirjanduse ja rahvaluule kateedri kogu

ERA = Eesti Rahvaluule Arhiivi rahvaluulekogu (1927-1944)

$\mathrm{H}=\mathrm{J}$. Hurda rahvaluulekogu 
KKI MT = KKI murdetekstid (1947-2001)

RKM = Eesti TA Fr. R. Kreutzwaldi nim (Riikliku) Kirjandusmuuseumi (nüüd Eesti Kirjandusmuuseumi) rahvaluule osakonna rahvaluulekogu (peamiselt alates 1945. aastast)

RKM, KP = Eesti TA Fr. R. Kreutzwaldi nim (Riikliku) Kirjandusmuuseumi (nüüd Eesti Kirjandusmuuseumi) rahvaluule osakonna rahvaluulekogu koolipärimuse kogu

\section{Kasutatud kirjandus}

Attardo, Salvatore 1994. Linguistic Theories of Humor. Berlin, New York: Mouton de Gruyter.

Boskin, Joseph 1997. Rebellious Laughter: People's Humour in American Culture. Syracuse, New York: Syracuse University Press.

Cray, Ed \& Eisenberg Herzog, Marilyn 1967. The Absurd Elephant: A Recent Riddle Fad. Western Folklore 26 (1). Berkeley \& Los Angeles: University of California Press, lk 27-36.

Dundes, Alan 2002. Kes on rahvas? Valik esseid folkloristikast. Tallinn: Varrak.

EKFA = Eesti kõnekäändude ja fraseologismide andmebaas - http://www.folklore.ee/ justkui/ Tartu: Eesti Kirjandusmuuseumi folkloristika osakond.

EM I = Eesti mõistatused I, 1-1350. Hussar, Anne \& Krikmann, Arvo \& Saukas, Rein \& Voolaid, Piret (koost). Krikmann, Arvo \& Saukas, Rein (toim). Tartu: Eesti Keele Sihtasutus, 2001.

EM II = Eesti mõistatused II, 1351-2800. Hussar, Anne \& Krikmann, Arvo \& Saukas, Rein \& Voolaid, Piret (koost). Krikmann, Arvo \& Saukas, Rein (toim).Tartu: Eesti Keele Sihtasutus, 2002.

Eisen, Matthias Johann 1890 [tiitellehel 1889]. Eesti rahwa mõistatused. Tartu: K. A. Hermann.

Eisen, Matthias Johann [1904]. Mõista, mis see on? Tallinn: K. Busch.

Eisen, Matthias Johann 1913. Eesti mõistatused. Tartu: Postimees.

Eisen, Matthias Johann [1914]. Mõista, mõista, mis see on: Mõistatused, keerulised küsimised ja mõistatuse jutud. Tartu: Postimees.

Gibbs, Raymond W. 1994. The poetics of mind: Figurative thought, language, and understanding. Cambridge: Cambridge University Press.

Kaivola-Bregenhøj, Annikki 2001. Riddles: Perspectives on the use, function and change in a folklore genre. Studia Fennica Folkloristica 10. Helsinki: Finnish Literature Society.

Kippar, Pille 1986. Estnische Tiermärchen. Typen- und Variantenverzeichnis. Folklore Fellows Communications 237. Helsinki: Suomalainen Tiedeakatemia.

Krikmann, Arvo 1992. Härjamari, vähirasv (Zoohübriididest ja -absurdidest paröömikas). Keel ja Kirjandus 11, lk 667-682. 
Krikmann, Arvo 1997. Sissevaateid folkloori lühivormidesse I: Põhimõisteid, žanrisuhteid, üldprobleeme. Tartu: Tartu Ülikooli Kirjastus.

Krikmann, Arvo 1999. Vanasõnad loomade identiteedist (Tüpoloogilisi memuaare). Mäetagused 12. Tartu: EKI folkloristika osakond, lk 52-86.

Lakoff, George \& Johnson, Mark 1999. Philosophy in the Flesh: The Embodied Mind and its Challenge to Western Thought. New York: Basic Books.

Lasteleht $=$ Lasteleht 1904, 1.

Lipponen, Ulla 1988. Kilon poliisi ja muita koululaisjuttuja. Helsingi: Suomalaisen Kirjallisuuden Seura.

Lipponen, Ulla 1995. Jauhot suuhun: Arvoitusvitsejä ja kompakysymyksiä. Helsinki: Suomalaisen Kirjallisuuden Seura.

LR = Laste Rõom 1938, 5 ja 8.

McDowell, John Holmes 1979. Children's Riddling. Bloomington \& London: Indiana University Press.

Meelej = Meelejahutaja 1885, 19 ja 21.

Merilai, Aarne 2003. Pragmapoeetika: kahe konteksti teooria. Tartu: Tartu Ülikooli Kirjastus.

Opie, Iona \& Opie, Peter 1967. The Lore \& Language of Schoolchildren. London \& Oxford \& New York: Oxford University Press.

Price, Roger 1953. Droodles. New York: Simon and Schuster.

Roemer, Danielle 1995. Riddles. Sutton-Smith, Brian et alii (toim). Children's Folklore: a source book. New York: Garland, lk 161-192.

Tähtr = Tähtraamat 1939. Tallinn: Ploompuu kirjastus 1938. [Kaanel: Aastavara 1939; Maja kalender 1939; Taluperenaise tähtraamat 1939].

Virtanen, Leea 1984 (esitrükk 1980). Lastenperinne. Helsingin yliopiston Kansanrunoustieteen laitoksen toimite 6. Helsinki: Helsingin yliopiston monistuspalvelu.

Voolaid, Piret 2002. Eesti piltmõistatused - http://ww.folklore.ee/Reebus. Tartu: Eesti Kirjandusmuuseum.

Voolaid, Piret 2003. Eesti liitsõnamängud - http://ww.folklore.ee/Sonamang. Tartu: Eesti Kirjandusmuuseum.

Voolaid, Piret 2004. Eesti keerdküsimused - http://ww.folklore.ee/Keerdkys. Tartu: Eesti Kirjandusmuuseum.

Õim, Asta 2000. Fraseoloogia sõnaraamat. Tallinn: Eesti Keele Sihtasutus.

Õim, Katre 2003. Võrdluste struktuurist ja kujundisemantikast. Reetor 2. Tartu: Eesti Kirjandusmuuseumi folkloristika osakond, Eesti Kultuuriloo ja Folkloristika Keskus. 


\title{
Summary
}

\section{Animal Lore in Estonian Riddle Periphery}

\author{
Piret Voolaid
}

Key words: animal lore, riddle subcategories: compound word games, conundrums, droodles

The study focuses on the use of animals in three major recently emerged subgenres of what has become to be called riddle periphery: conundrums, compound word games, and droodles.

- Compound word games are direct "wh"-questions, e.g., Q: How do you put an elephant in the fridge? A: 1. Open the fridge. 2. Put the elephant inside. 3. Close the fridge.

- Droodles mostly consist of a visual image serving as the question and the description of the image serving as the answer, e.g., Q: What is this A: Four elephants sniffing an orange.

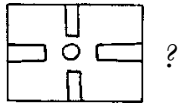

- Compound word games mostly use the initial formula "What" or "Which kind?" and expect, instead of an adjective, a compound word as an answer, such as Mis tõugu hobune on parim ujuja? Vastus: Merehobune. [ Q: What horses swim the best? A: Seahorses.]

Animals appear as characters in these riddles in great numbers but in specific riddle subcategories the animal paradigm manifests in a unique way.

About one fourth of all Estonian conundrums feature animal names, and like in folk narratives (folktale, joke, tall tale) or other genres of verbal art (fable, cartoons, plays) the animal is associated with highly diverse imagery. Quite often these genres include anthropomorphic personification, where human characteristics attributed to a zoological creature tend to function as specific stereotypes and the animals often talk about us and serve as embodiments of humans. The use of animal characters who act as representatives of different types of humans allows safe ridiculing of the vices of humans and the society. In other minor forms of folklore (proverbs and phrases), the most popular animals are generally local domestic animals and fowl, but the most popular animal characters in Estonian conundrums are rather exotic (elephant, hippopotamus, etc.). One reason for this is perhaps the predominance of international material (e.g., elephant jokes originating from the Anglo-American culture area) in the Estonian riddle material, and the exotic stranger is still appealing in folklore texts. The situations and settings in which the animal characters are presented in conundrums (and droodles) are often distanced from the reality, which is why the material associated with animals can be seen as zoological absurdity.

The compound word games point to the favouring of compounds in the Estonian language, and the frequent occurrence of zoological creatures as elements of the Estonian compound words prove that the animal kingdom has greatly inspired the naming 
of things, phenomena and qualities with compounds. Compound word games are most often based on fixed metaphors (e.g., kohtukull 'legal hawk', raamatukoi 'bookworm'), in which the figurative image has become secondary and the user no longer recognises it.

In Estonian language, animals tend to be used as the end constituent of the compound noun, though there are many others in which the animal name figures as a genitive substantive in the attributive constituent.

One third of the entire corpus of Estonian droodles depict representatives of the animal kingdom, though the most popular ones are those with characteristic appearance (the hare's long ears, the elephant's trunk, the camel's humps, the giraffe's long and spotted neck, the zebra's stripes), because these are simple to sketch and thus are easily adopted in the tradition.

The text samples used in the article have been taken from online folklore databases of Estonian conundrums (Eesti keerdküsimused, http://www.folklore.ee/Keerdkys, approx. 25,000 texts), of Estonian compound word games (Eesti (liit)sõnamängud, http:// www.folklore.ee/Sonamang, approx. 5,000 texts) and of Estonian droodles (Eesti piltmõistatused, http://www.folklore.ee/Droodles, approx. 7,500 texts). 